\title{
Against Liberty \\ Adorno, Levinas and the Pathologies of Freedom
}

\author{
Eric S. Nelson
}

Abstract: Adorno and Levinas argue from distinct yet intersecting perspectives that there are pathological forms of freedom, formed by systems of power and economic exchange, which legitimate the neglect, exploitation and domination of others. In this paper, I examine how the works of Adorno and Levinas assist in diagnosing the aporias of liberty in contemporary capitalist societies by providing critical models and strategies for confronting present discourses and systems of freedom that perpetuate unfreedom such as those ideologically expressed in possessive individualist and libertarian conceptions of freedom.

Keywords: asymmetrical ethics, capitalism, equality, freedom, libertarianism, social justice, solidarity

\section{Introduction}

The human subject is bewitched by the idea of its own freedom as if by a magic spell. (Adorno 2006: 220)

Freedom is typically taken in the popular Western imagination - even if only rhetorically and ideologically - to be the original source (as freedom of the will to formulate, choose and determine its actions) and ultimate value (as the liberty to pursue one's own will and interests as one sees fit) for action. Negative liberty, defined as independence from an arbitrary external will and authority if not necessarily the condition of law established through consensus, is the defining feature of classical liberalism and contemporary capitalist-oriented libertarianism. Yet, already in Locke, liberty as free consent is contrasted with while remaining bound to coercion. Locke's conception of liberty validates, to varying degrees, war, slavery, colonialism and the appropriation of others' collective common property - such as the land of the Native Americans - in order to make it usefully and individually one's own. ${ }^{1}$

It is apparent in Locke's political writings how the theodicy of the liberal Englishman's individual freedom legitimates the exploitation of those incapable of realising such liberty. Likewise, the greater amount of wealth produced by capitalist inequality justifies its unequal distribution according to 
the agent's individual initiative in Adam Smith and orthodox interpretations of capitalism. Nineteenth-century American individualists including Emerson and Thoreau celebrated the self-initiated responsibility and generosity of the individual, and presented solitude as a condition of a deeper sociability and solidarity. Nonetheless, the popular authoritarian libertarianism of contemporary politics does not recognise this free generosity of noble souls, or acknowledge community as a desired consequence of liberty, but rather locates the primary virtues of liberty in the fear and distrust of others and the politics of mass resentment. ${ }^{2}$

The current condition of North American political life, which I will adopt as a concrete example, indicates how 'freedom' - despite its critical potential and utopian promise for individuals and communities - can be problematic in validating what should otherwise not be justified. Freedom can become, as David Harvey has described, 'a freedom to dominate and exploit others' (Harvey 2000: 173). Insofar as capitalist freedom justifies 'a politics of unequal rewards', not only vast inequalities of wealth but more active forms of exploitation and marginalisation, it is questionable whether freedom and liberty are the unconditional goods they are construed to be when they are deployed in an ideological and mythical manner that is pathological and destructive to the flourishing of individual and common life. This pathology of freedom, with its dialectic of self-assertion - against those who are different, weaker, poor, foreign, 'the enemy' who is not with us - and authoritarian submission - to those whose image is 'like us', 'the friend' who is with us - is an all too apparent tendency in American media, politics and social life even as there are tendencies that challenge it.

I will address the philosophical issue of the value of freedom in this essay with an eye towards this contemporary situation. There is a propensity in modern Western philosophy to demand and reify the absolute freedom of the ego and glorify the possessive individual, conceptualized through individual spontaneity and striving for self-preservation. A series of thinkers in the twentiethcentury have questioned this priority of the self, and the identity demanded by its logic, for the sake of the other person and that which remains non-identical (Schroeder 1996: 101). Frantz Fanon described how 'some want to impose their presence on the world, fill it up with their presence', a 'some' that includes groups as well as individuals who want to absorb and exclude others according to their own standard of freedom. This is the freedom of the self that sets itself against others in order to assert and stabilise its own sense of self. Fanon noted that 'one German philosopher described the process as the pathology of freedom' (Fanon 2008: 200).

Fanon is referring to Günther Anders, who - in a neglected yet trenchant and prescient essay - detailed the corrosive and pathological characteristics of self-assertive freedom. The nihilistic freedom that neglects and negates the other is a condition of National Socialist totalitarianism according to Anders, demonstrating how an ideology of freedom - the notion of a unique 'German 
freedom' in this case - is complicit with practices of domination. Instead of being the contrary of freedom, as libertarian theory maintains, freedom is intertwined with domination as the will to fill the world with oneself and make it conform to one's own identity (Anders 1936/37: 22-54; 2009: 278-310). Negative liberty, the defining characteristic of a particular variety of liberalism from Locke to contemporary libertarianism, functions in this context not only as a rationalisation for indifference and irresponsibility towards others, but as a validation for active injustice. As a social ideology, if not necessary as philosophical theorising, it opens the space for the realisation of one's freedom over others who do not deserve to partake in it, because of God, fate or the market that invisibly and ineluctably determine all merit and value.

To evaluate critically contemporary capitalist societies, an inflationary understanding of 'liberalism' needs to be challenged. 'Liberalism' should not be understood in such a broad sense that classical liberalism and republicanism, capitalist-oriented libertarianism and varieties of contemporary liberalism compatible with more robust forms of social responsibility cannot be distinguished. This paper, in light of ethical and social-political argumentation unfolded in the works of Levinas and Adorno, is concerned with the variety of liberalism defined by the priority of negative liberty and possessive individualism.

\section{The Critique of Freedom}

In the ideological assertion of freedom, with its anti-intellectualist ressentiment, freedom appears as the opposite of critique and as the negation of the need to answer to the other. Identifying the habitual and unthought with nature, critique is suspected of being the destruction of natural liberty in restraining routine unreflective action by potentially placing it into question and calling the self to offer an account of itself. Adorno and Levinas are both acutely aware in their own ways of how rational freedom betrays itself. Even the ostensive critical freedom of self-reflection and the give and take of reasons in communication, praised by more socially oriented and progressive thinkers of autonomy from Kant and Mill to Dewey and Habermas, can become an impediment to rather than the fulfilment of freedom as consent becomes the coercion to assent.

The problematic of self-negating freedom, noted by Hegel and Marx, was intensified in the critical social theory of the Frankfurt School. Theodor Adorno and Max Horkheimer traced the aporias and collusions of autonomy and heteronomy and spontaneity and instrumentality in Western modernity, diagnosing society's constructed image of freedom as the ideological destruction of the autonomy promised by the Enlightenment. The ideology of individualism, in which individuals are mass-produced copies of what the individual is projected to be, corresponded with the concrete individual being 
undermined and absorbed by manipulated things and images in the pseudoindividualistic conformity of the culture-industry and mass-consumerism:

The total effect of the culture industry is one of anti-enlightenment, in which, as Horkheimer and I [Adorno] have noted, enlightenment, that is the progressive domination of nature, becomes mass deception and is turned into a means for fettering consciousness. It impedes the development of autonomous, independent individuals who judge and decide consciously for themselves. These, however, would be the precondition of a democratic society which needs adults who have come to age in order to sustain itself and develop. (Adorno 1991: 92; cf. 54-5)

Kantian autonomy and the Enlightenment's promise of rational independence is reductively narrowed to 'free self-interested choices' between predetermined brands and prefabricated activities, mature individuation is blocked and frustrated, and free spontaneous activity is reduced to a repressive entertainment and relaxation, a reactive realm of escape and irresponsibility rather than the flourishing and fulfilment of life. ${ }^{4}$

Adorno in particular has shown how a purportedly democratic popular culture, which advertises every new technological and cultural fad as liberation, can be dialectically a vehicle for its opposite. For Adorno, 'the ideology of freedom and autonomy' camouflages an 'actual state of unfreedom and dependence' (Cook 1996: 64). The culture industry, 'the most inflexible style of all', is the 'most effective form of ideology today', since it is no longer dependent on any particular ideology or perspective but appropriates and transverses them all (Adorno and Horkheimer 2004: 104; Adorno 2006: 78).

Adorno's analysis of how popular culture and its appearance of freedom were constituted by the culture industry, commodity fetishism and consumerism has been criticised as undemocratic elitism. Yet questioning massproduced culture and its illusion of freedom is an interrogation of self-negating democracy and self-undermining freedom. Adorno's analysis does not entail a denial of the emancipatory potential of the Enlightenment and modernity, as critics of Adorno such as Habermas charge, but the diagnosis of its ideological uses and deformations (Bronner 2004: 5).

It might also be argued that even if Adorno's criticism of consumerist individualism is accurate, it does not follow that the liberal capitalist account of free market liberty is wrong, since it only entails that such liberty has not yet been effectively achieved. This argument reflects the dialectical ambiguity of freedom as future promise and negated present. The critique of liberal freedom need not necessarily be the denial of freedom, as the libertarian objection suggests. Critics of existing conditions of unfreedom in advanced capitalist societies can distinguish between freedom's role in the structural inequalities of society, its ideological falsification that excuses these inequalities of class, gender, and race and its interruptive and transformative promise in relation to the present.

Adorno's analysis developed Marx's thesis of the heteronomy of individual in face of the autonomy of the commodity in commodity fetishism (Hammer 
2006: 29-31). Still one cannot be reduced to the other to the extent that the promise of freedom and the fact of domination are dialectically mediated without thereby being identical (Habermas 1992: 28). It is, according to Adorno, the logic of war and totality to posit only one or the other, for and against, and friend and enemy (Adorno 1974: 131-2). It is the incompleteness of ideological mediation, in identity and social totality, and the prospect and promise of its interruption that are articulated by Adorno and also - in a non-dialectical language - Emmanuel Levinas. ${ }^{5}$

\section{Questionable Liberty}

According to Peter Dews, the question 'why human beings prefer an inadequate, self-destructive freedom to genuine freedom' raises difficult issues of human motivation and the prospect of evil (Dews 2008: 130). The conformist and destructive tendencies of individualistic and democratic freedom have been at issue from Plato's diagnosis of the feverish conditions of the Athenian polis to Hegel's dialectic of the self-destruction of the French Revolution to de Tocqueville's portrayal of the tyranny of the majority and conformity that characterises the political life of the United States (Marcuse 1970: 96; Harold 2009: xxvi-xxviii).

Liberty can be betrayed in the name of liberty, and authentic freedom can be ideologically distorted and masked by inauthentic and pathological freedom. Yet perhaps freedom is much more questionable than the distinctions between authentic and inauthentic, negative and positive, freedoms suggests. Perhaps prioritising freedom is not as innocent and natural as it appears, but intrinsically questionable as a betrayal of the other person. In Levinas's works in particular, one finds a radical questioning of the freedom of the ' $\mathrm{I}$ ' in its naïve and irresponsible spontaneity insofar as this is oblivion to the other (Levinas 1996a: 17). Freedom as a sense of heightening power and increasing enjoyment without concern or obligation towards others, asserting its place in the sun unconcerned with any other (except to evade the other's shadow), is arbitrary and tyrannical (Levinas 1999a: 15, 23; Bloechl 2000: 33).

Levinas connects this feeling of power with the conatus and struggle for existence that he, in parallel to Adorno's analysis of the socio-pathological sublimation of self-preservation, identifies as central to modern philosophy's preoccupation with the self, its compulsive self-concern, and its perseverance in being. At the same time, insofar as this historically formed egoism is tied up with a calculative self-interest that is defined by social conventions, this form of self and subjectivity is a product of the ritualised logic of sacrifice. Despite its numerous suspicions of morality, justice and altruism, this sacrificially constituted self is conformist, moralistic and vindictive to those who do not follow the rules of the game with its sacrifices and privileges. Adorno and Horkheimer uncover in the Dialectic of Enlightenment and in their studies on 
the authoritarian personality how strategies of adaptive self-preserving reason become maladaptive, irrational and authoritarian through their redeployment in unequal systems of exchange structured by power. In this configuration of exchange and sacrifice, the individual's pursuit of the good life and the 'natural goods' prized by classical capitalist liberalism - life, liberty and happiness - systematically reproduce damaged life.

While the freedom of the subject is typically prioritised and valorised in modern Western philosophy, Levinas concludes that responsibility necessarily precedes and is the condition of any freedom: 'To be obliged to responsibility overflowing freedom, that is, responsibility for the others ... The pure passivity that precedes freedom is responsibility' (Levinas 1987: 136). ${ }^{6}$ This passivity is not the docile weakness of egos administered by the culture industry, locked into their private infantile patterns of consumption, and lacking the integrity, maturity and strength to resist their subordination to the social totality, depicted by Adorno. Levinas's passivity is not a departure and safe-haven from the social but entanglement in the life, needs and suffering of others. Passivity signifies the one-for-the-other of responsibility that is the necessary if not sufficient condition for social-political equality. My dependence on the other - to the point of being a substitute for and prisoner to the other - is the very facticity of freedom; the fact that freedom is without excuse and must answer for itself before others. It 'must justify itself' in response to the other person (Chanter 2001: 270). Genuine - that is, social other-oriented - freedom is impossible without the on-going critique to which it must answer. This critique is not initiated by itself and its autonomy in the Kantian fashion but by its potential irresponsibility and injustice to the other person.

Anti-cognitivist interpretations of Levinas deny that he engages in argumentation or critique, as these concern discursive truth and validity claims. Levinas questioned the concept of critique, in its Kantian and general sense, and so there is supposedly no critique in Levinas. Nonetheless, Levinas frequently engages in practices of critical reading and reflection: the interrogation of institutions, practices and reasons (Harold 2009: xvi, 191). Levinas not only engages in reading as 'cloture', as Simon Critchley claimed, but reading as questioning as he disputes, reverses and transverses the claims of the philosophers (Critchley 1999: 145). Levinas engages in questioning and critique in the sense of responding otherwise. One concept that is critically shown by Levinas not to mean what it is usually assumed to mean is that of freedom.

Without the strategies of critical social theory, Levinas exposed in his own way the ideological function of freedom understood as egoistic indifference towards others or as a playful spontaneity in undermining responsibility. Levinas criticises philosophers such as Eugen Fink and Jeanne Delhomme who 'demand an unconditional freedom without responsibility, a freedom of play' (Levinas 1996a: 90; 1996b: 53). ${ }^{7}$ Levinas's inclusion of the non-cognitive then is not an exclusion of argumentation and reasoning from the ethical, even as reflection and conceptualisation are derivative to the encounter with and 
exposure to the other. All knowing, all discourse, already presupposes the encounter of self and other even if it is suppressed, distorted and bracketed. But the encounter does not end communication and reflection; it is their transient point of departure.

Levinas's rethinking of freedom places freedom in risk while not being able to abandon or eliminate it either: 'One is not against freedom if one seeks for it a justification' (Levinas 1990a: 302). But, as Levinas points out against Heidegger and Sartre's portrayal of freedom as the spontaneity of the self, 'freedom is not justified by freedom' (Levinas 1990a: 303; cf. Kleinberg 2005: 275). Although responsibility is anarchic, it goes beyond the self's intentions and calculations and involves a displacement in which there can be an encounter between self and other, such that one can only speak of a 'difficult freedom' confronted not by mere resistance and limitation but by the legitimate and inescapable claims of the other. Consequently, for Levinas, an unlimited or unconditional freedom that does not acknowledge or respond to the other's address, suffering and illness - as in the denial of healthcare - is not freedom but neglect and tyranny.

Some interpreters deemphasise the radicalism of Levinas's argumentation. Rudi Visker, for example, claims: 'Instead of limiting my freedom - as is the case in pathology - Levinas' trauma establishes it, or "invests" it'; yet this investment is the limitation of the freedom of play 'without responsibility' (Visker 2004: 89; cf. Nancy 1993: 189). Such attempts to make Levinas sound less challenging to standard notions of freedom - that he is only limiting its playfulness not limiting my freedom per se or questioning the priority of freedom - de-radicalise Levinas's claim to the weak thesis that freedom has sources outside of itself but that these external origins should not change how we should conceive of freedom. This is explicitly not the case for Levinas, however, "[i]t is for the free self to fix the limits of this responsibility ... [b]ut it can do so only in the name of that original responsibility ...' (Levinas 1990a: 225). Freedom is not self-initiating and then either morally or pathologically limited; freedom is already configured through the tension of an ethical response to others and complicity with their betrayal. Levinas's freedom is accordingly not only an initial traumatism that is integrated and superseded; it is insomnia, wakefulness and vigilance (Levinas 1998b: 70; 1999b: 65).

Such readings do not adequately articulate the pathological freedom that is a crucial concern for Levinas and for those who interpret contemporary political appeals to freedom as involving an ethical promise while being acutely ideological and pathologically caught up in domination, exploitation, neglect and violence. Levinas does not abandon the word freedom, yet he does radically question its self-presentation since freedom is often the legitimation for avoidance, excuse and violence. Levinas thus asks how free persons 'can be subject to reason without losing their freedom' and how we can 'give meaning to this notion of finite freedom without striking a blow against freedom in its finitude [...] how can freedom be, while also being limited?' (Levinas 1999b: 
96; 2000: 178). This prospect of a responsible freedom proceeding from and in response to the other suggests an alternative to the aporetic dynamic of moralising and irresponsibility that characterises ideological discourses of individualism and liberty.

\section{Asymmetrical Freedom}

Another problematic interpretative strategy suggests that Levinas is too willing to abandon freedom and its privileges. In his account of Levinas based on his interpretation of the Frankfurt school, C. Fred Alford misses an important dimension of Levinas's thought when he contends that: 'Against freedom of the will in all its guises, Levinas posits freedom of the abandonment of the will, an openness to the world' (Alford 2002: 121). Levinas overtly and repeatedly rejects Heidegger's openness, letting and releasement (Gelassenheit). Levinas does not argue for an altruistic and receptive openness without will, but rather for a dependence and passivity that is active responsibility to the other and the other's freedom. ${ }^{8}$ Although Adorno rejects overusing the language of passivity and receptivity as the abandonment of critical thought, associating this language with Heidegger, it should be noted that for Levinas it is the point of departure for discourse and the concept that arrive 'after the fact' yet which still do arrive and mediate the relations between self and other. Consequently the immediacy of the ethical is always caught up in the complicity of the political.

I would argue that Levinas is not advocating the abandonment of the will nor a complete giving over (Hingabe) and subservience of the self, with its potential reactionary political consequences feared by critics who identify his thought with their interpretation of Heidegger's failings. Levinas shows how the will is already informed by responsibility from the beginning and without evasion: 'To reflection, this responsibility is astonishing in every way, extending all the way to the obligation to answer for the freedom of the other, all the way to being a responsibility for his responsibility' (Levinas 1998b: 70). Freedom as responsibility for the freedom of the other confounds the philosophy of the primacy of the self, as it entails that my freedom is implicated in the fate and freedom of others, and I cannot deny them on behalf of my freedom.

It is a false alternative to conclude that either Levinas negates freedom by responsibility to the other or he must leave the priority of the freedom of the subject intact and unaltered. The configuration of freedom is rethought through asymmetry, and the asymmetrical freedom between self and other. ${ }^{9} \mathrm{I}$ do not choose my or the other's freedom, instead I am constituted through others. My 'responsibilities cannot be freely chosen', as there is an asymmetry between freedom and responsibility, other and self, which contests the Kantian model of reciprocal autonomy and the mutual deduction of autonomy and responsibility in the 'fact of reason'. (Ziarek 2001: 89). More than this, I am 
more responsible and less free than the other due to the passivity constitutive of the ethical: 'Pure passivity preceding freedom is responsibility. But the responsibility that owes nothing to my freedom is my responsibility for the freedom of others' (Levinas 2003: 55).

Passivity means that I am not free to pick and choose in relation to the other; I respond and must respond infinitely much to the chagrin and discomfort of self-interested calculation and egoism: 'It implies responsibility which should surprise, nothing being more opposed to freedom than the nonfreedom of responsibility. It is the coincidence of freedom and responsibility that constitutes the I, doubled and encumbered with itself (Levinas 1990a: 271). Does such a strategy make freedom superfluous to ethical responsibility? (Bergo 2003: 120). Does this movement from the other subordinate the individual too radically to the ethical or the religious? Hent de Vries notes that: 'What is at stake here, however, is an asymmetrical freedom in which God in the very donation of His presence retains the initiative at every single moment' (1999: 60). Levinas often voices this priority of the ethical above all else with reference to God, as when he claims: 'It is a responsibility that precedes freedom, which would mean precisely belonging to God, a unique belonging which, anterior to freedom, does not destroy' (Levinas 1994a: 107; 1999b: 58). Yet this is religion determined by the ethical. It is always the other that places the ethical demand upon me: 'Suffering the weight of the other man, the "me" [moi] is called to uniqueness by responsibility'.10

If there are authors who find asymmetrical ethics too burdensome and demanding in calling us to our non-indifference and responsibility for others, other detractors contend that asymmetrical freedom is inherently conservative and elitist in negatively privileging myself over others as if injustice were solely up to me (Zafirovski 2009: 321). Slavoj Žižek, to take one example, asks whether this 'self-questioning' is not - through the kind of reversal of position interrogated by Hegel and Nietzsche in their depiction of the dialectic between master and slave - in fact 'self-privileging': 'does this asymmetry not effectively end up in privileging one particular group that assumes responsibility for all others [and] embodies in a privileged way this responsibility [...?]' (Žižek et al. 2006: 155). Are not such fears of asymmetry warranted insofar as neoconservative ideologues (1) demand an aggressively interventionist international politics based precisely on the asymmetrical responsibility and exceptionalism of the United States, and (2) criticise ethical symmetry and its associated liberal freedoms for the sake of an authoritarian paternalistic tradition that they supposedly undermine (Kalb 2008).

Concerns about the political consequences of asymmetry are intensified in the case of Levinas as his ethical-political scepticism has been interpreted as part of postmodern and communitarian critiques of liberal Western modernity. Levinas is often seen as rejecting liberalism and modern Western political thought rather than rethinking its sources (Batnitzky 2006; Harold 2009). Levinas's critique of liberalism, however, is not only based in pre-modern 
traditional Jewish and Greek sources. It should be understood in the modern context of his overt reliance on and appeals to the French republican tradition as he deploys in his political argumentation the progressive universalising republican language of the 'rights of man', and liberty, equality, 'fraternity' (Caygill 2002: 7-9, 151-8). It is a genuine issue, forcefully raised by Simon Critchley, whether the classical republican language of the 'rights of man' and 'fraternity' is inherently masculine or whether it can be reinterpreted as 'human rights' and 'solidarity' (Critchley 2007: 94).

Levinas is an inheritor of the radical republicanism of Rousseau and the French Revolution insofar as solidarity, which is the asymmetrical ethical condition of the liberty of each individual, has priority over the liberty that can neglect or deny the other's suffering. It is this ethical claim on the political through the intervention of the third party, and the third-person perspective abstracted from the asymmetry of the I-thou encounter, which calls for the institutionalisation of justice, equality and liberties that also threatens their ethical sources. Processes of institutionalisation are a necessary infidelity to the primacy of the ethical that would keep institutions and their impersonal logic in check. In this context, as Adorno also warns of the liquidation of the individual for the sake of the impersonally administered socialist or capitalist collective, Levinas both agrees and disagrees with the Marxist prioritisation of the collective social and political sources for obtaining individual liberties for all (Harvey 2000: 173). These structures must be equally for the sake of all (as political) and asymmetrically for the other individual (as ethical).

Levinas's use of the republican - and at time the socialist - political tradition is simultaneously its critique insofar as these political registers - whether liberal, republican or socialist - can become the means to subordinate rather than recognise the other. The 'ideology of freedom and equality' in its modern technological and consumerist context, is the foundational ideology for liberalism and conservatism, capitalism and socialism (Stivers 2008: 29). The underlying philosophical ideology of freedom remains deeply questionable (Nancy 1993: 46). This ideology - with its political consequences of indifference and oblivion towards others - needs to be confronted and freedom itself reconsidered to the extent that autonomy functions to isolate the subject and deny relatedness (Reiss 2002; Rothenberg 2009: 201).

Although the affirmation of relatedness in difference and responsibility in alterity entails risking acting in place of the other rather than only for her or him, it is the asymmetrical difference of responsibility itself that does not allow the self to replace the other. My responsibility is always conditioned by being towards the other. This involves an externalisation and expropriation of the self that disrupts responsibility being understood as privileged mastery over others and challenges absorbing and controlling the other in the name of being responsible for the other. Asymmetry entails an irrevocable difference between self and other that paternalistic responsibility wants to remove for the sake of an identity that hierarchically identifies and ranks individuals, groups 
and peoples. There is then a radical difference between anarchic differencepreserving and hierarchical difference-integrating asymmetries such that they cannot be assumed to be the same.

Moreover, since Levinas's interpretation of asymmetrical responsibility both exaggerates and limits responsibility, it problematises ossified asymmetrical hierarchies, reductive symmetrical conformism and the avant-gardist esoteric assumption of power that purports to act in the best interests of equality. The denial of asymmetry and difference risks becoming totalitarian indifference and depersonalisation, where there are some who enjoy power while others are pressed to conform or are eliminated under the guise of equality. This betrayal occurred, for instance, in what Levinas described as 'the supreme paradox in which the defense of the person is inverted into Stalinism' (Levinas 1998a: 191). This remark illustrates Levinas's appreciation and criticism of the history of socialism insofar as its political instrumentalisation and institutionalisation undermined its ethical motivation.

Just as there is a pathological equality, there is a pathology of freedom in the indifference and irresponsibility towards the other of libertarian freedom, where some enjoy the leisure of their freedom while others - who are 'not my concern', as I am not my brother's keeper as Cain said of Abel - experience toil, suffering and injustice. In reply to such a denial of answerability, Levinas remarks:

It is as if, behind being, one could hear the sarcastic laughter of irresponsibility, for which the freedom within being is not free enough; but beyond being there would extend the goodness of unbounded responsibility, for which that freedom is not generous enough. (Levinas 1996b: 54)

Responsibility, as irrevocably asymmetrically greater for me than for anyone else, is inevitably a heteronomy and subordination to the other for the leisurely freedom for which responsibility is always too much: 'One thus reproaches one's freedom for losing itself in the burden of responsibility for oneself and others; and concern for others can, of course, appear as a form of subjection, as an infinite subjection' (Levinas 2001: 192). This subordination is justice, and there is no ethical subject without such subjection. Ethical individuation occurs through dependency, relatedness and substitution rather than through self-creation. There is, however, not only subordination but the anarchy of the good - irreducible to calculation and rules - prior to and constituting freedom (Levinas 1981: 138).

\section{The Pathology of Freedom and the Idolatry of Liberty}

Nietzsche's Zarathustra warned of the new idol of the state, requiring idolatry and human sacrifice from good and bad alike, such that the human individual 
begins only where the state ends (Nietzsche 1980: vol. 4, 61-4). Nietzsche like de Tocqueville describes the conformity of social relations beyond the state. Precisely in the valorisation of the individual, the individual is lost through the media and instruments that are supposed to preserve and support it. There is also, as Adorno repeatedly diagnosed in his analysis of the American culture industry, a cult and idolatry of individualism - at times more dangerous than that of the state, because more effective through accepted conformity - that is the destruction of actual individuals.

The fixated typology of what it means to be an individual reifies individual life and does not allow individuals to be different than mass-produced individuals. These forms are not only externally imposed, and thus more easily remedied, but structure the pre-reflective and non-conceptual dimensions of individual life where the ethical takes place for Levinas (Adorno 1991: 105). Although Adorno likewise brings into play the non-cognitive and mimetic as a challenge to identity-thinking, anti-cognitivism based on the pre-reflective without critique and argumentation reproduces without any prospect of challenging damaged life. The natural and the transcendent are not unambiguous, they are already stylised and restyled through society, history and culture even if they are irreducible to them.

Freedom as a natural capacity or transcendent referent is already ideological. As ideological, freedom can function to compel and integrate without interruptive or transformative promise or prospect. Günther Anders consequently diagnosed how autonomy and authenticity can be the compulsion of power demanding surrender before those interests that put individuals in their place, negating their freedom in the name and fantasy of their freedom (Anders 2009: 307-8).

Adorno notes how in antiquity and modernity negative liberty, the separation of freedom from freedom in society, undermines the freedom to actively participate in social life:

The situation in which the individual was vanishing was at the same time one of unbridled individualism, where 'all was possible...'.

Freedom from society robs the individual of the strength for freedom. (Adorno 1974: 149-50)

That is, asocial freedom limited to a reified and absolutised private self is not the 'natural negative freedom' envisioned in libertarianism but a denial of the freedom that participates in and helps shape society (Adorno 2006: 266). Unlike the responsibility of non-identical sociality, the absolutisation of the separated and unconditional self and its 'theodicy of the individual' impose conformity by excluding non-identity (Adorno 2006: 57, 60). The privatised and reified freedom of the self is correlated with its unfreedom in the social totality. In Levinas's language, the freedom of the self is the imperialism of the same (Levinas 1990a: 85-7). Far from being unconditional, such freedom 
is suspect as socially mediated illusion and as ethical irresponsibility. It denotes not only avoidance but 'the determination of the other by the same', instead of the openness of the same to the other, and is in need of a reversal in which it learns its responsibility to others (Hofmeyr 2009: 19).

The abstract and ideologically configured individual of fetishised and massproduced 'individualism' betrays and negates actual concrete individuals, as negative liberty becomes lack of autonomy in society and the self is reduced to conformity and consumption: 'the official culture's pretence of individualism which necessarily increases in proportion to the liquidation of the individual' (Adorno 1991: 35). Adorno concludes on these grounds - not unlike de Tocqueville a century earlier - that American individualism and libertarianism are in fact deeply conformist in their simultaneous demand for 'pragmatic' adjustment and accommodation to the existing order that provides the standard for what should be considered popular, successful and useful.

The libertarian ideology of absolute freedom not only masks power and violence, cynically assuming that persons have equal opportunities yet make unequal effort to realise their aspirations, it actively restricts actual difficult liberties - which are conditional, fragile and plural - to the extent that its freedom is only the freedom to accept social compulsion (Rose 1996: 60; Adorno 2006: 197). The narcissistic liberty of the self becomes the harshest legalism applied to others, as genuine difference is reduced to the identity of exchange in the name of the abstract individual (Adorno 1973: 146).

The bourgeois individual is constructed from its socially trained instincts to dream of realising itself, its feeling of power, and uniqueness in economic exchange and yet is used, exhausted and replaced as an identical product in an indifferent systematic process greater than it. As already intimated in Adam Smith's invisible hand and Hegel's cunning of reason, the idea of asocial freedom motivates social individuals who reproduce a fateful whole. The 'individual' is the mass-produced instantiation of a category, concealed in an aura of false uniqueness that has been cheaply designed to appeal to each person's desire to feel special. But this individual is pathologically conformist, afraid of people, ideas and cultures that are perceived as other, and easily manipulated by the advertising and 'spin' that create and regulate its desires. The heroic virile individual, a product of the culture industry and the system of exchange that it expresses, proves to be impotent in regard to the forces that constitute it and dictate what kind of individual it should be. As freedom dialectically undermines itself, and as my own idea of freedom claims to defend while actually betraying the freedom of others, extreme vigilance is needed to confront our equivocal freedom that is both an ideological fabrication, designed to compensate individuals for their actual lack of freedom, and an immanent emancipatory promise (Adorno 2006: 198).

Levinas, akin to Anders and Adorno in this respect, is concerned with the aporia and self-betrayal of freedom as well as its prophetic promise (Levinas 1998a: 60; Chalier 2002: 75-7). Even as freedom can be a denial of responsi- 
bility and justice, freedom presupposes the society that threatens to destroy it (Levinas 1990c: 241; cf. Ajzenstat 2001: 51). It is not merely that responsibility is intimate and personal and mass society undermines such responsibility (Alford 2002: 124). While recognising the material conditions and needs that constitute a vulnerable and fragile subject, it is only through responsibility and ethical love that freedom is invested, elected and individuated as unique (Levinas 2001: 192-3). Levinas's thinking of responsibility must risk and challenge the dangers of the transformation of asymmetrical responsibility into the empty ethical piety and wretched moralistic posturing in the name of humanity of which Adorno consistently warns with an ethical intent. Adorno's criticisms of morality and the language of 'minima moralia' that he turns against bourgeois and other conventional moralities that reify the ethical life of individuals is itself ethically motivated (cf. Bernstein 2001: 143).

Levinas's responsibility is not that of an isolated subject heroically assuming all the burdens of the world, since this conditional self is inevitably social and oriented towards others in the community of neighbours and in face of the stranger. The ethical basis of the political should not lead to the moralistic exclusion of the political for the sake of the ethical. Levinas's vision of responsible freedom is interlinked with his understanding of classical republicanism (Caygill 2002: 7-9, 151-8). In particular, freedom is only one dimension of the classical French republican triad, which Levinas reinterprets rather than abandons, and is bound up with - the heteronomous conditions of ethical autonomy - equality and solidarity: 'One's duty regarding the other who makes appeal to one's responsibility is an investing of one's own freedom. In responsibility, which is, as such, irrecusable and non-transferable, I am instituted as non-interchangeable' (Levinas 1994b: 125; 1994a: 104).

Responsibility, elected and invested freedom, is more than autonomy or the free limitation of freedom that comes and goes as it wishes (Levinas 1999a: 148). Describing the transition of the Jewish people from slavery to a condition of receiving the moral law, Levinas reverses the standard version of the Nietzschean narrative of slave-morality:

The negative freedom of those set free is about to transform itself into the freedom of the Law, engraved in stone, into a freedom of responsibilities. Is one already responsible when one chooses responsibility? (Levinas 1990b: 37).

In contrast with such a difficult responsible freedom that does not deny the poor and the weak but responds to their distress, Levinas describes how in the freedom to exploit others, economically and otherwise, the law comes to repress the freedom it ought to make possible. There is no freedom without the moral law even as the institutionalisation of law can institutionalise freedom in ways that produce injustice and suffering. However, in the unlimited freedom of desire that knows no laws or boundaries in relation to others, and in distinction from the anarchic desire for the other in transcendence, love 
without law becomes pleasure without love (Levinas 1990c: 284-5; Peperzak 1995: 190). Others become for the freedom and pleasure of the ego - in its authoritarian imperialism and pragmatic instrumentalism - impediments to be removed and objects of calculation to be controlled. Yet within this nexus of instrumental power relations rests the possibility of encounter and, in the contingent exposure and risky exteriority of the encounter, the reversal of the self that is the opening towards the other.

\section{A Rousseauian Conclusion}

In The Government of Poland, Rousseau cautioned against appeals to liberty that in reality reaffirm servitude, noting the importance of citizens mutually digesting and cultivating freedom in contrast with its rhetorical abuses. Rousseau concluded that: 'Liberty is a food that is good to taste but hard to digest: it sets well only on a good strong stomach' (Rousseau 1985: 29). Liberty requires digestion, the hardship and 'difficult freedom' of living and working not only for oneself but for others.

Levinas and Adorno are not of course 'against liberty' as such. Their thinking is informed by, respectively, progressive Rousseauian republican and Marxist social democratic sources that they critically rethought and appeals to the anarchic promise of freedom that disrupts the indifferent functioning and autopoietic reproduction of the present social totality. Totality is neither interrupted by the egotistical self striving for more in the name of its freedom nor by what Adorno and Horkheimer describe as 'the wretched moralistic attempts to propagate humanity as the most rational of means' (2004: 91). While the latter leaves the systematic sources of injustice uncontested and intact, the former is an expression of the relentless reproduction of the structural processes of exchange. This acquisitive ego, despite its intentions and wishes to 'simply be itself', reflects and intensifies the social totality that both Adorno and Levinas recognise as structured by the identity of exchange. The promise of freedom cannot then come from me, the sovereignty of the subject, but must interrupt my freedom and its illusory power from beyond it. It approaches from the abject and the other to whom it is systematically denied, disturbing the ego-oriented self and alarming those who ideologically identify their present advantages with natural liberty.

Despite their own complicities with instrumental reason and identity thinking, Levinas and Adorno's writings suggest critical models and indicate strategies for diagnosing and confronting the structurally formed pathologies associated with reified visions and the manipulative misuses of liberty. The problem with freedom is that it is a privilege of the few. Despite its undeniable accomplishments and promise and potential for letting individuals pursue their own course and flourish, insofar as this course is pre-empted by conformity, irresponsibility and indifference to others' well-being, and the negation of what 
is different in the construction of and resentment against the alien, the foreign and the enemy, the modern reified conception of liberty is conjoined with the actual lack of liberty in its enactment, institutionalisation and practice.

Possessive individualism, libertarianism and liberalism in its classical Lockean and capitalist senses are not the neutral theoretical positions in accord with 'nature' or 'natural law' that their proponents interpret them to be. They are socially formed positions even as the occupants of these roles deny their own sociality and entanglement with the others who they ignore and disavow. This is by no means a novel claim but its importance calls for its repetition: the doctrine of natural liberty serves to mask and justify socially contrived injustice. These ideological positions can be accordingly - as they are lived and practiced and not merely thought - the symptom and mask, if not the poison itself, of a social condition appropriately described as the pathology of freedom and idolatry of liberty. This is fitting to the extent that there is a willingness if not eagerness to engage in the sacrifice of actual concrete individuals and their ability to participate in society and have a degree of well-being without persistent fear of financial and personal ruin.

Eric S. Nelson is Associate Professor of Philosophy at University of Massachusetts, Lowell. He has coedited several works, including Addressing Levinas (Northwestern University Press, 2005), Rethinking Facticity (SUNY Press, 2008), and the Continuum Companion to Heidegger (Continuum, forthcoming). He has also published over thirty articles and book chapters on nineteenth- and twentieth-century European philosophy.

\section{Notes}

1. For extended discussions of these issues in Locke, see Tully (1993: ch. 5), Arneil (1996), Bernasconi and Mann (2005: 94-5).

2. Although this paper supports the conclusion that there are deeper connections between self-assertion and negation of the other, we should bear in the mind the differences between elite theoretically oriented libertarianism and its popular 'vulgar' incarnations. There is also at least a theoretical distinction between libertarian theory, 'which is racism-free by construction', and 'racism camouflaged behind libertarian rhetoric', as discussed in J. E. Roemer et al. (2007: 77).

3. On the dialectical ambivalence of nature, which serves as both an ideological and critical concept in Adorno, see Nelson (2011: 105-26; 2012a: 319-41; 2012b).

4. Cf. Marcuse (1971: 224), Bowie (1997: 289), Scoglio (1998: 17), Eagan (2006: 292).

5. On the controversy over popular culture, see Wheatland (2009: 132-4).

6. On the dialectical image that indicates both its ideological character and its potential disruption, see Adorno (2006: 171). On the ethical beyond the ideological, see Levinas (1998b: $3-14)$. 
7. See, respectively, Bernasconi (2005: 170-84) and Hearfield (2004: 24).

8. Cf. Batnitzky (2006: 20) and Beals (2007: 74).

9. On the status of critique in Levinas and Derrida, in a reading that risks assimilating Levinas's ethics to Derrida's deconstruction, see Bernasconi (2007).

10. On the problematic character of anti-cognitivist and anti-normative interpretations of Levinas, see Perpich (2008: 89-90, 126).

11. Cf. Harold (2009: 23-4).

12. On this passage, note Chanter (2001: 270) and Dudiak (2001: 158).

13. Levinas distinguishes passivity from receptiveness in Levinas (1998: 89); he contrasts openness and letting with invocation and summoning in 'Is Ontology Fundamental?' (1996a: 5-6); on responsibility for the other's freedom, and heteronomy as the condition of autonomy, see Levinas (1994a: 104; 1999b: 58).

14. For a classic statement of the problem of asymmetrical freedom, see Wolf (1980: 151-66). For a more general consideration of asymmetrical ethics in Levinas, see Nelson (2010: 454-66).

15. Levinas (2000: 176); on the religious as a modality of the ethical, see Nelson (2008: $91-$ 109 and 2009: 177-207).

16. Adorno (2006: 212). On de Tocqueville, Adorno and America, see the important work by Offe (2005).

\section{References}

Adorno, T. 1973. Negative Dialectics, tr. E. B. Ashton. New York: Continuum Books. 1974. Minima Moralia: Reflections on a Damaged Life, tr. E. F. N. Jephcott. London: Verso.

1991. The Culture Industry, ed. J. Bernstein. London: Routledge. 2006. History and Freedom: Lectures 1964-1965, ed. R. Tiedemann, tr. Rodney Livingstone. Cambridge: Polity Press.

Adorno, T. and M. Horkheimer. 2004. Dialectic of Enlightenment: Philosophical

Fragments, tr. Gunzelin S. Noerr. Stanford: Stanford University Press.

Ajzenstat, O. 2001. Driven Back to the Text: The Premodern Sources of Levinas'

Postmodernism. Pittsburgh: Duquesne University Press.

Alford, C. F. 2002. Levinas, the Frankfurt School, and Psychoanalysis. Middletown:

Wesleyan University Press.

Anders, G. 1936/37. 'Pathologie de la liberté, essai sur la non-identification', Recherches philosophiques 7: 22-54.

2009. 'The Pathology of Freedom: An Essay on Non-identification', tr.

Katharine Wolfe, Deleuze Studies 3(2): 278-310.

Arneil, B. 1996. John Locke and America: The Defence of English Colonialism.

Oxford: Clarendon Press.

Batnitzky, L. F. 2006. Leo Strauss and Emmanuel Levinas: Philosophy and the

Politics of Revelation. Cambridge: Cambridge University Press.

Beals, C. 2007. Levinas and the Wisdom of Love: The Question of Invisibility. Waco:

Baylor University Press. 
Bergo, B. 2003. Levinas between Ethics and Politics: For the Beauty that Adorns the Earth. Pittsburgh: Duquesne University Press.

Bernasconi, R. 2005. 'Levinas and the Struggle for Existence', in E. S. Nelson, K. Still, A. Kapust (eds) Addressing Levinas. Evanston: Northwestern University Press, 170- 184.

2007. 'The Crisis of Critique and the Awakening of Politicisation in Levinas and Derrida', in M. McQuillan (ed.), The Politics of Deconstruction: Jacques Derrida and the Other of Philosophy. London: Pluto Press, 81-97.

Bernasconi, R. and A. Mann. 2005. 'The Contradictions of Racism: Locke, Slavery, and the Two Treatises', in A. Valls (ed.), Race and Racism in Modern Philosophy. Ithaca: Cornell University Press, 89-107.

Bernstein, J. M. 2001. Adorno: Disenchantment and Ethics. Cambridge: Cambridge University Press.

Bloechl, J. 2000. Liturgy of the Neighbor: Emmanuel Levinas and the Religion of Responsibility. Pittsburgh: Duquesne University Press.

Bowie, A. 1997. From Romanticism to Critical Theory: The Philosophy of German Literary Theory. London: Routledge.

Bronner, S. 2004. Reclaiming the Enlightenment: Toward a Politics of Radical Engagement. New York: Columbia University Press.

Caygill, H. 2002. Levinas and the Political. London: Routledge.

Chalier, C. 2002. What Ought I to Do? Morality in Kant and Levinas, tr. J. M. Todd. Ithaca: Cornell University Press.

Chanter, T. 2001. Time, Death, and the Feminine: Levinas with Heidegger. Stanford: Stanford University Press.

Cook, D. 1996. The Culture Industry Revisited: Theodor W. Adorno on Mass Culture. Lanham: Rowman and Littlefield.

Critchley, S. 1999. The Ethics of Deconstruction: Derrida and Levinas. West Lafayette: Purdue University Press.

Critchley, S. 2007. 'Five Problems in Levinas's View of Politics and a Sketch of a Solution to Them', in M. Diamantides (ed.), Levinas, Law, Politics. London: Routledge-Cavendish, 93-105.

de Vries, H. 1999. Philosophy and the Turn to Religion. Baltimore: Johns Hopkins

University Press.

Dews, P. 2008. The Idea of Evil. Malden: Blackwell.

Dudiak, J. 2001. The Intrigue of Ethics: A Reading of the Idea of Discourse in the Thought of Emmanuel Levinas. New York: Fordham University Press.

Eagan, J. 2006. 'Unfreedom, Suffering, and the Culture Industry: What Adorno Can Contribute to a Feminist Ethics', in R. Heberle (ed.), Feminist Interpretations of Theodor Adorno. University Park: Pennsylvania State University Press, 277-299. Fanon, F. 2008. Black Skin, White Masks. New York: Grove Press.

Habermas, J. 1992. Autonomy and Solidarity. London: Verso.

Hammer, E. 2006. Adorno and the Political. London: Routledge.

Harold, P. J. 2009. Prophetic Politics: Emmanuel Levinas and the Sanctification of Suffering. Athens: Ohio University Press.

Harvey, D. 2000. Spaces of Hope. Berkeley: University of California Press.

Hearfield, C. 2004. Adorno and the Modern Ethos of Freedom. Aldershot: Ashgate.

Hofmeyr, B. 2009. Radical Passivity: Rethinking Ethical Agency in Levinas.

Dordrecht: Springer. 
Kalb, J. 2008. The Tyranny of Liberalism. Wilmington: ISI Books.

Kleinberg, E. 2005. Generation Existential: Heidegger's Philosophy in France, 1927-1961. Ithaca: Cornell University Press.

Levinas, E. 1981. Otherwise Than Being, or Beyond Essence, tr. A. Lingis.

Pittsburgh: Duquesne University Press.

1987. Collected Philosophical Papers, tr. A. Lingis. Dordrecht: Nijhoff. 1990a. Difficult Freedom: Essays on Judaism, tr. S. Hand. Baltimore: Johns

Hopkins University Press.

1990b. Nine Talmudic Readings. Bloomington: Indiana University Press. 1990c. Totality and Infinity: An Essay on Exteriority, tr. A. Lingis.

Pittsburgh: Duquesne University Press.

1994a. Beyond the Verse: Talmudic Readings and Lectures, tr. G. D. Mole.

Bloomington: Indiana University Press.

1994b. Outside the Subject, tr. M. B. Smith. Stanford: Stanford University

Press.

Press.

1996a. Basic Philosophical Writings. Bloomington: Indiana University

1996b. Proper Names, tr. M. B. Smith. Stanford: Stanford University Press.

1998a. Entre Nous: Thinking-of-the-Other, tr. M. B. Smith and B. Harshav.

New York: Columbia University Press.

1998b. Of God Who Comes to Mind, tr. B. Bergo. Stanford: Stanford

University Press.

1999a. Alterity and Transcendence. New York: Columbia University Press.

1999b. New Talmudic Readings, Pittsburgh: Duquesne University Press.

2000. God, Death, and Time, tr. B. Bergo. Stanford: Stanford University

Press.

2001. Is It Righteous to Be?: Interviews with Emmanuel Levinas, ed. and tr.

Jill Robbins. Stanford: Stanford University Press.

2003. Humanism of the Other, tr. Nidra Poller. Urbana: University of Illinois

Press.

Marcuse, H. 1970. Reason and Revolution: Hegel and the Rise of Social Theory.

Boston: Beacon Press.

1971. Eros and Civilization: A Philosophical Inquiry into Freud. Boston:

Beacon Press.

Nancy, J-L. 1993. The Experience of Freedom. Stanford: Stanford University Press.

Nelson, E. S. 2008. 'The Secular, the Religious, and the Ethical in Kierkegaard and

Levinas', in C. Welz, K. Verstrynge (eds.), Despite Oneself: Subjectivity and Its

Secret in Kierkegaard and Levinas. London: Turnshare, 91-109.

2009. 'Levinas and Early Confucian Ethics: Religion, Rituality, and the

Sources of Morality', Levinas Studies, vol. 4: 177-207.

2010. 'Who Is the Other to Me? Levinas, Asymmetrical Ethics, and Social-

political Equality', Mono Kurgusuz Labirent 8-9: 454-66.

2011. 'Revisiting the Dialectic of the Environment: Nature as Ideology and

Ethics in Adorno and the Frankfurt School', Telos 155: 105-26.

2012a. 'Aesthetics, Ethics and Nature in Adorno', in J. Carroll, S. Giles and

M. Oergel (eds), Aesthetics and Modernity from Schiller to the Frankfurt School.

Peter Lang, 319-341. 
2012b. 'Levinas and Adorno: Can There Be an Ethics of Nature?', in W. Edelglass, J. Hatley, C. Diehm (eds), Facing Nature: Levinas and Environmental Thought. Pittsburgh: Duquesne University Press, 109-133.

Nietzsche, F. 1980. Sämtliche Werke: Kritische Studienausgabe in 15 Bänden, hrsg. von Giorgio Colli und Mazzino Montinari. Berlin: de Gruyter.

Offe, C. 2005. Reflections on America: Tocqueville, Weber and Adorno in the United States. Cambridge: Polity.

Peperzak, A. T. 1995. Ethics as First Philosophy. New York: Routledge.

Perpich, D. 2008. The Ethics of Emmanuel Levinas. Stanford: Stanford University Press.

Reiss, T. J. 2002. Against Autonomy: Global Dialectics of Cultural Exchange. Stanford: Stanford University Press.

Roemer, J. E., L. Woojin and K. van der Straeten. 2007. Racism, Xenophobia, and Distribution: Multi-issue Politics in Advanced Democracies. New York: Russell Sage Foundation.

Rose, G. 1996. Mourning Becomes the Law: Philosophy and Representation. Cambridge: Cambridge University Press.

Rothenberg, M. A. 2009. The Excessive Subject: A New Theory of Social Change. Cambridge: Polity.

Rousseau, J-J. 1985. The Government of Poland, tr. W. Kendall. Indianapolis: Hackett.

Schroeder, B. 1996. Altared Ground: Levinas, History, and Violence. New York: Routledge.

Scoglio, S. 1998. Transforming Privacy: A Transpersonal Philosophy of Rights. Westport: Praeger.

Stivers, R. 2008. The Illusion of Freedom and Equality. Albany: State University of New York Press.

Tully, J. 1993. An Approach to Political Philosophy: Locke in Contexts. Cambridge: Cambridge University Press.

Visker, R. 2004. The Inhuman Condition: Looking for Difference after Levinas and Heidegger. Dordrecht: Kluwer Academic.

Wheatland, T. 2009. The Frankfurt School in Exile. Minneapolis-London: University of Minnesota Press.

Wolf, S. 1980. 'Asymmetrical Freedom', Journal of Philosophy 7(7): 151-66. Zafirovski, M. 2009. Democracy, Economy, and Conservatism: Political and Economic Freedoms and Their Antithesis in the Third Millennium. Lanham: Lexington Books.

Ziarek, E. P. 2001. 'The Ethical Passions of Levinas', in T. Chanter (ed.), Feminist Interpretations of Emmanuel Levinas. University Park: Pennsylvania State University Press, 78-96.

Žižek, S., E. L. Santner and K. Reinhard. 2006. The Neighbor: Three Inquiries in Political Theology. Chicago: University of Chicago Press. 